\title{
Investigating participation level in Foreign Language Classrooms through the analysis of Communicative Discourse
}

\author{
$\mathrm{M}^{\mathrm{a}}$ Isabel Velasco Moreno \\ University of Córdoba, Spain \\ Received: 5 August 2010 / Accepted: 15 July 2011 \\ ISSN: $1697-7467$
}

\begin{abstract}
Foreign Language classes have not been sufficiently investigated probably due to the difficulty of finding a successful method of analysis. We propose a model of Communicative Discourse Analysis (CODAM) with a taxonomy of Verbal and Non Verbal acts in Initiation, Response and Follow Up moves (I, R, F) according to the intention of each speaker's contribution to communicative discourse. By applying CODAM to the corpus obtained from actual classes in Andalusia, we have been able to compare not only the extension of communicative discourse but also speakers' participation level and learners' use of English in the classroom.

Keywords: FL classes, discourse analysis, students' L2 oral output, communicative acts, L2 teaching.

Investigación del nivel de participación de los hablantes en la clase de lengua extranjera a través del análisis del discurso comunicativo

RESUMEN: El desarrollo de las clases de LE no ha sido suficientemente estudiado dada la dificultad de encontrar un adecuado método de análisis. Presentamos un modelo de Análisis del Discurso Comunicativo (CODAM) con una taxonomía de actos Verbales y No Verbales para movimientos de Iniciación, Respuesta o Continuación según la intencionalidad del hablante. La aplicación de CODAM al corpus obtenido de clases actuales de L2 en Andalucía, ha permitido conocer la extensión del discurso comunicativo en las distintas sesiones; comparar los niveles de participación oral así como la utilización de la lengua inglesa en el aula.

Palabras clave: Clases de Lengua Extranjera, análisis del discurso, producción oral del alumnado en L2, actos comunicativos, enseñanza L2.
\end{abstract}

\section{INTRODUCTION}

Over the last four decades there has been a great concern about foreign language teaching. Bellack et al (1966) was one of the first attempts to describe what takes place within the instructed setting. In spite of researchers' agreement on the necessity of knowing more about the teaching-learning process, we believe that classes in general, and L2 classes in particular, have not been sufficiently studied.

Research has been done from different perspectives. From a linguistic approach, Sinclair and Coulthard (1975) proposed a model of discourse analysis based on functionalism suggested by Firth (1957) and later developed by Halliday (1973). 
In the last part of the $1980 \mathrm{~s}$ and in the $1990 \mathrm{~s}$ the desire to investigate classes increased greatly. The study of FL classrooms has often been focused on what teachers had planned to do during their classes. It has been considered of great relevance to learn about decisions taken by L2 teachers in relation to the selection of objectives, contents, methodology and evaluation criteria before they encountered the teaching situation.

However, there was a change of mind at the end of the 20th century. The systematic study of what takes place in the language classroom should not be only part of academic studies. It was thought that teachers could and should explore their own classes. Then, trying to introduce teachers to classroom investigation, several methods of research were developed specially connected with observation (Hopkins, 1985).

Although most of research has focused on teacher's behaviour in class there are some investigations centred on what pupils think and feel about L2 classes. Through a learning diary written after class, students point out their opinion and impressions about the teaching and learning process indicating what they have learned or thought to be the most relevant aspect in that specific class (Bailey, 1991). Students' uptake has also been investigated

Most research is related to what takes place before or after the teaching process in L2 classrooms but little about the real teaching-learning process. When the process is the focus, only small parts of it, or specific behaviours have been investigated such as errors and correction (Chaudron, 1988).

On the other hand, experimental studies where two classes doing similar activities are compared have also been carried out. In our opinion, these studies can't really show a global vision of the whole instruction setting because the investigation is observing just one element in a specific moment of the classroom and they do not show a natural setting because one, or more than one variable has been controlled.

Some recent studies show the importance of using transcriptions to help teachers' self-reflection (Harfitt, 2008). Following McCarthy (1991), we believe that it is necessary to investigate discourse to understand oral encounters. That is why our main aim in this paper is to show how revisiting situations from an observer's point of view can help teachers to understand better certain attitudes or comments that took place in class and it should not be limited to small fragments of the process as it is possible to analyse the whole process. We are suggesting a method to analyse communicative discourse based on Discourse Analysis proposed by Birmingham School and on later contributions in Conversation Analysis (Tsui; 1994) and on the tripartite conception of Language (Poyatos 1994). Although CODAM; the Communicative Discourse Analysis Model presented here, could be applied to any type of communicative encounter among individuals, in this paper we are going to apply it to classroom discourse in order to gain a wider knowledge about relevant aspects concerning the teaching-learning process.

\section{2. ОвJеCTIVes}

Our first aim in this research is to investigate the extension of L2 classes. In Spain, a class period lasts 1 hour, but seconds or minutes do not help to show the length of any class. 
- How can we measure the extension of a class?

In order to observe how much discourse has been generated in each period of class, we have developed a Communicative Discourse Analysis Model (CODAM). By applying it to the updated real corpus we have obtained, we will be able to answer the following question:

- Do all L2 classes share the same quantity of discourse?

After investigating the length of classes we will be able to get deeper insights on particular questions like:

- Do teachers and learners participate in the same way in class?

Or, in other words,

- Is there an equal contribution to oral discourse between the group formed by learners and the teacher in L2 classes?'

We are specially interested in analysing learners' oral participation in L2 classes. The question is:

- How much do L2 learners speak in English during the English class?

\section{Participants}

Participants' selection was a long process as it was not easy to find schools willing to allow class recording. Although some schools did not object to their classes being observed, they were reluctant to being video recorded. This difficulty led us to avoid video-recording, as it also required special permission from parents. We have to thank the six schools and teachers who welcomed us as observers in their classes.

The study was carried out in six instructed settings in Andalusia, a region in the south of Spain. All students are children (under 14 years old) who have been learning L2 (English) for less than four academic years.

There are groups of pupils from different ages because the main factor in this investigation is the number of years learning L2.

* Absolute beginners. G2 and G3.

* One year L2 learning experience: G1.

* Three years learning L2: G4 and G5.

* Four years in contact with L2: G6.

Due to important changes in the Spanish Educational System during the last years, in our data base there are students from 0 to 4 years of experience as learners of English as L2. The age range varies because some of them started to study L2 when they were 8 ; others at 6 , and in the private language school, students could start at 4 .

Different types of school have been selected: public, semi-public, private school and even a Language Academy (non-compulsory). We aimed to include both rural and city schools too.

The corpus used for this research was obtained from real classes in the period (2002 - 2008).

Teachers show differences between them, specially relating to age, L2 learning and teaching experience. Some teachers are quite young and have just finished University studies, while others have considerably more teaching experience. They have different 
academic levels too. Some of them have the required degree to be an English teacher at Primary and first cycle in Secondary schools in Spain, but others have a second bachelor degree in English Philology. Further training has been obtained at University, in Official Language Schools, in Teachers' Centres or abroad.

There is not an equal number of male and female teachers. Only one of the teachers in this study is a man which is not surprising as it seems to be more female than male English teachers in Andalusia.

According to the ratio, it is important to know that Spanish educational law fixes a maximum of 25 pupils per group in Primary and 30 students in Secondary.but, as we can see on table 1 the number of students per group varies from one group to another. Birth rate and location are some of the reasons but the small size of G5 is due to pedagogical reasons. It is inserted in a rural school where different academic levels are mixed and they have to be divided for some subjects according to the hours of tuition they have to receive in each level.

Table 1. Group of students.

\begin{tabular}{|c|c|c|}
\hline Group & Level/ age & ratio \\
\hline G1 & Preschool, 5 years old & 15 \\
\hline G2 & $6 / 7$ years old & 10 \\
\hline G3 & $3^{\circ}$ E.P.O / 8 years old & 22 \\
\hline G4 & $6^{\circ}$ E.P.O./12 years old & 21 \\
\hline G5 & $6^{\circ}$ E.P.O./ 12 years old & 9 \\
\hline G6 & $1^{\circ}$ E.S.O./13 years old & 28 \\
\hline \multicolumn{2}{|c|}{ Total } & 105 \\
\hline
\end{tabular}

\section{Methodology}

The methodology followed can be divided into five main stages:

1. Observation and recording period.

2. Classroom discourse transcription.

3. Application of Sinclair and Coulthard's model of Discourse Analysis.

4. Design of the Communicative Discourse Analysis Model. (CODAM).

5. Application of the model and corpora analysis.

\subsection{Observation and recording period}

We started an observation period joining each group avoiding disturbing students from their activities. Classes were audio recorded and notes were taken when any significant paralanguage element or movement was made. 


\subsection{Classroom discourse transcription}

Classes transcription was a slow, difficult and time-consuming task.

\subsection{Application of Sinclair and Coulthard's model of discourse analysis}

The main difficulty anyone encounters when trying to analyse discourse is how to measure discourse. It is certainly not an easy task. One way of measuring it could be counting the number of words produced by each speaker but it would not be significant enough if taking into account that communicative discourse is not only formed by words.

A different way of measuring discourse could be just counting speakers' turns but, in that case, we had to give the same value to all speech turns although we are conscious that they do not normally have the same extension as some speakers produce longer speech turns than others.

We strongly agree with those researchers believing that the best way is investigating what takes place within the classroom. Sinclair \& Coulthard (1975) proposed a model of analysis studying acts, turns and Initiation, Response and Follow up moves. So, we started to apply their model of discourse analysis to our data but we found several important problems. Although at the beginning, we could easily recognise some elements of their taxonomy in our corpus we soon realised that we had to add more elements to their taxonomy because the Birmingham school focused mainly on the description of what the teacher did in class but very little related to students' behaviour. For our purpose, to find out the extension of L2 classes through the analysis of the discourse developed in class, we have to take into account all speakers in class, not just the teacher. Undoubtedly, their excellent work fitted very well when it was created (1975) when master classes were very common and as a consequence teachers did most of the speaking. However, after notable changes in education, nowadays we have to think that students are not just seated passively in class receiving information. We have to think that there are a lot of participants in class and if we want to analyse classroom discourse, we need to add more elements to the initial discourse analysis taxonomy. These extra elements need to be related not only to students' participation but also to any participant, as the role of listener and speaker changes many times throughout any class period.

\subsection{Design of the Communicative Discourse Analysis Model (CODAM)}

The following questions should be answered: What is discourse?, Is discourse just what speakers say in class or is it something else?

We believe that it is necessary to consider more than words or sentences. We prefer the term Communicative Discourse instead of Discourse to describe the interaction among individuals. In Communicative Discourse communication made through words and sentences is included as well as what is communicated without language, that is, through kinesics, and paralanguage. We fully agree with Poyatos (1994) on the fact that paralanguage and kinesics are relevant elements in communication. In fact, in many cases they are as important as, or even more important than language itself. Communicative Discourse includes Verbal and Non Verbal elements which mix together, helping to establish 
communication among participants. So, setting our bases on the Birmingham model, considering the tripartite notion of communication (Poyatos, 1994), basing on Pragmatics and findings made on Conversation Analysis (Tsui, 1995) and on the notion of episode (Salaberri, 1999) we suggest that, in any communicative context, but specially in L2 classes, the existing communicative discourse is formed by the link of different episodes that contain exchanges formed by communicative turns, which are also formed by communicative moves of Initiation, Response and Follow up. Each move is formed by one or more communicative acts that can be either Verbal (V) or Non Verbal (NV).

Although in many classes the quantity of communicative turns produced by teachers is similar to the ones produced by pupils, it is easy to discover that they do not have the same extension, as teachers' turns seem to be longer most of the times. The research of what takes place within turns is then, needed. We believe that, any turn can be formed by, at least, one communicative move. When a turn is formed by one communicative move we consider it a simple communicative turn and when there are more than one it could be considered as a complex communicative turn.

Following the model proposed by the School of Birmingham, once we have detected and identified moves we should know which elements compound each move. As verbal moves are formed by verbal acts (Sinclair and Coulthard, 1975) we believe that Non Verbal moves are equally formed by Non Verbal acts. Any Verbal Act can be as communicate as any Verbal one because it transmits not only information but also speakers' intention.

The model of analysis proposed to reach a better knowledge of the FL classes is based on the study of the smallest pieces that compound the communicative discourse generated during the teaching-learning process in the classroom context.

To develop this model of analysis we have, in a figurative way, taken communicative discourse like a puzzle and removed all the pieces from it. Then, taken the smallest piece, the communicative act, as the unit of analysis we have tried to rebuild the mosaic, to make the jigsaw again but this time interpreting why each fragment has been used in that particular moment during the teaching-learning process.

As we can see, the Communicative Discourse Analysis model presented is based on Sinclair and Coulthard's model of Discourse Analysis (1975) as we believe that their findings opened the window to a whole new world of research. Trying to help to increase the knowledge about FL classrooms we have adopted many elements of their model although we have adapted it, changing, modifying and adding new ones. From a pragmatic perspective and using the emphatic function we have situated ourselves on both students' and teachers' side to understand the meaning of the communicative acts implemented by them.

The following table shows a list of the possible communicative acts that, in our opinion, can take place in FL classes. There are three groups of acts: (1) acts used in Initiation Moves; (2) acts belonging to Responding Move and (3) acts in the Follow up Move. Besides the act name it is shown if it is Verbal or NV. Sometimes both possibilities are possible. 
Table 2a. Taxonomy of Communicative Acts.

\begin{tabular}{|c|c|c|}
\hline INITIATION MOVE & VERBAL & NON VERBAL \\
\hline Nomination & $\mathrm{X}$ & $\mathrm{X}$ \\
\hline Elicit:read & $\mathrm{X}$ & \\
\hline Directive:read & $\mathrm{X}$ & $\mathrm{X}$ \\
\hline Directive:instruction & $\mathrm{X}$ & $\mathrm{X}$ \\
\hline Directive:translation & $\mathrm{X}$ & $\mathrm{X}$ \\
\hline Directive repeat & $\mathrm{X}$ & $\mathrm{X}$ \\
\hline Elicit:translation & $\mathrm{X}$ & \\
\hline Elicit:repeat & $\mathrm{X}$ & \\
\hline Elicit:confirm & $\mathrm{X}$ & \\
\hline Elicit:agree & $\mathrm{X}$ & \\
\hline Elicit:pseudoinformation & $\mathrm{X}$ & \\
\hline Lecturing 1 & $\mathrm{X}$ & \\
\hline Lecturing 2 & $\mathrm{X}$ & \\
\hline
\end{tabular}

Table 2b. Taxonomy of Communicative Acts.

\begin{tabular}{|c|c|c|}
\hline ANSWERING MOVE & VERBAL & NON VERBAL \\
\hline Reading & $\mathrm{X}$ & \\
\hline Translation & $\mathrm{X}$ & \\
\hline Repetition & $\mathrm{X}$ & \\
\hline Confirmation & $\mathrm{X}$ & $\mathrm{X}$ \\
\hline No confirmation & $\mathrm{X}$ & $\mathrm{X}$ \\
\hline Agreement & $\mathrm{X}$ & $\mathrm{X}$ \\
\hline Give information & $\mathrm{X}$ & $\mathrm{X}$ \\
\hline Give pseudoinformation & $\mathrm{X}$ & $\mathrm{X}$ \\
\hline NVR (positive reaction) & & $\mathrm{X}$ \\
\hline NVR (negative reaction) & & $\mathrm{X}$ \\
\hline No agreement & $\mathrm{x}$ & $\mathrm{X}$ \\
\hline
\end{tabular}

Table 2c. Taxonomy of Communicative Acts.

\begin{tabular}{|c|c|c|}
\hline FOLLOW UP MOVE & VERBAL & NON VERBAL \\
\hline Endorsement & $\mathrm{X}$ & $\mathrm{X}$ \\
\hline Acknowledgement & $\mathrm{X}$ & $\mathrm{X}$ \\
\hline No acknowledgement & $\mathrm{X}$ & $\mathrm{X}$ \\
\hline Refusal & $\mathrm{X}$ & $\mathrm{X}$ \\
\hline
\end{tabular}

We have not distinguished between teachers communicative acts and students communicative acts as it depends on the role played by participants at any moment. 
When teachers or students act as speakers they use different moves and acts than when they are acting as listeners. It also depends on the person they are addressing.

\subsection{CODAM application to our corpus linguistics and results}

After finding a way to measure discourse we have applied it to our previously recorded and transcribed corpus linguistics, obtaining relevant data from which we have drawn our conclusions related to: (i) classes extension; (ii) speakers' participation level and (iii) students' use of English during L2 classes.

\section{Analysis AND Results}

Results obtained from CODAM application have been divided into three sections:

* Related to the length of communicative discourse in each analysed class.

* Connected with speakers' participation level in L2 classes.

* Related to students' verbal discourse in English.

\subsection{Results related to the extension of communicative discourse in FL classes}

We have tried to check if all classes share a similar extension of communicative discourse. As we have previously stated selecting the correct unit of analysis is an extremely important issue because depending on that, research conclusions would be completely different. We have three options: (a) turns, (b) moves or (c) acts made by the teacher $(\mathrm{T})$ and students (Sts).

We can compare results taking these three possibilities.

\section{A) First possibility}

Let's consider the communicative turn as the unit of analysis:

Table 3 shows the communicative turns made by teachers and students.

Table 3. Communicative Turns in G2.

\begin{tabular}{|cc|c|c|c|}
\hline & \multicolumn{2}{|c|}{ Subtotal } & \multirow{2}{*}{ Total } \\
\cline { 1 - 3 } & T & Sts & \\
\hline Communicative turns & 158 & 203 & 361 \\
\hline Audio Material & 13 & & & 13 \\
\hline Total Communicative turns & 13 & 158 & 203 & 374 \\
\hline
\end{tabular}

Two main observations can be made from data on table 3 :

1. The length of the communicative discourse in class is only 374 communicative turns.

2. Students' participation in class is higher than teachers' participation because they make more communicative turns (203 versus 158). 
We could conclude that in this class children participate more than the teacher.

\section{B) Second possibility}

If, instead of considering communicative turns as the unit of analysis to investigate the length of classroom discourse we choose the communicative move we obtain different results.

Table 4. Communicative Moves in G2.

\begin{tabular}{|c|c|c|c|}
\hline & T & Sts & Total \\
\hline Verbal Moves & 185 & 153 & 338 \\
\hline Non Verbal Moves & 43 & 85 & 128 \\
\hline Total communicative moves & 228 & 238 & 466 \\
\hline
\end{tabular}

Different observations can be made here:

1. classroom communicative discourse has a longer extension (466 communicative moves versus 374 turns)

2. students' contribution to discourse is slightly superior to teacher's contribution (238 moves versus 228).

In the first and second possibility, students participation in class seems to be superior to teacher's participation. Maybe this should be expected as there are many more students than teachers in class but let's see results if we take into consideration the third possibility.

\section{C) Third possibility}

Let's consider the Communicative Act as the unit of analysis.

Table 5. Communicative Acts in G2.

\begin{tabular}{|c|c|c|c|}
\hline & T & Sts & Total \\
\hline Total Verbal Acts & 235 & 151 & 386 \\
\hline Total Non Verbal Acts & 42 & 85 & 127 \\
\hline Total Communicative Acts & 277 & 236 & 513 \\
\hline
\end{tabular}

Observations:

(1) classroom discourse is considerably higher than in the other two possibilities (513 acts versus 466 moves or 374 turns)

(2) the whole group of students participate less than the teacher. All students in class make 236 communicative acts while the teacher realizes 277 .

Our teaching experience leads us to think that results obtained from this third possibility are more credible. For this reason, we are absolutely convinced that it is necessary to take the communicative act as the unit of analysis if we wish to obtain real data. 
In our database we have checked that in all L2 analysed classes there is an equal or a superior number of communicative acts than moves, and the same number or more communicative moves than communicative turns.

Table 6 shows the length of communicative discourse in terms of communicative acts found in our corpus.

Table 6. Extension of L2 classes.

\begin{tabular}{|l|c|c|c|c|c|c|c|c|c|c|c|c|}
\hline & \multicolumn{2}{|c|}{ G1 } & \multicolumn{2}{c|}{ G2 } & \multicolumn{2}{c|}{ G3 } & \multicolumn{2}{c|}{ G4 } & \multicolumn{2}{c|}{ G5 } & \multicolumn{2}{c|}{ G6 } \\
\hline & G1-1 & G1-2 & G2-1 & G2-2 & G3-1 & G3-2 & G4-1 & G4-2 & G5-1 & G5-2 & G6-1 & G6-2 \\
\hline Communicative Acts & 376 & 385 & 683 & 513 & 472 & 395 & 222 & 508 & 458 & 328 & 563 & 344 \\
\hline
\end{tabular}

Great differences have been found among groups. Comparing G1 and G2 it is possible to appreciate how the longest class (G1-1) is almost half (G2-1). Surprisingly, it is possible to find great differences within the same group (G4- 1 versus G4-2)

Now, we think that the answer to the previous question is not. It seems obvious on table 6 that L2 classes are formed by a different quantity of discourse. Even classes belonging to the same group of participants have different length.

After checking extension differences according to the quantity of acts, we focus on speakers' contribution to discourse.

\subsection{Results related to speakers' participation level}

Our starting point here is:

- Do teachers and learners participate similarly in class? Or, in other words,

- Is there an equal contribution to discourse between learners and teacher in L2 classes?

To answer these questions, we have searched all communicative acts, that is, all Verbal (VA) and Non Verbal acts (NVA) made by speakers during the whole period of class in each classroom. Tables $7 \mathrm{a}$ and $7 \mathrm{~b}$ show the total number of VA and NVA made by speakers, helping to understand how communication has been built.

Table 7a. Verbal and Non Verbal acts.

\begin{tabular}{|c|c|c|c|c|c|c|c|c|c|c|c|c|}
\hline & \multicolumn{4}{|c|}{$\mathrm{G} 1$} & \multicolumn{4}{|c|}{$\mathrm{G} 2$} & \multicolumn{3}{|c|}{$\mathrm{G} 3$} \\
\hline Acts & $\mathrm{G} 1-1$ & $\%$ & $\mathrm{G} 1-2$ & $\%$ & $\mathrm{G} 2-1$ & $\%$ & $\mathrm{G} 2-2$ & $\%$ & $\mathrm{G} 3-1$ & $\%$ & $\mathrm{G} 3-2$ & $\%$ \\
\hline Verbal & 352 & $93,6 \%$ & 350 & $90,9 \%$ & 594 & $86,3 \%$ & 386 & $75,2 \%$ & 444 & $93,9 \%$ & 370 & $90,7 \%$ \\
\hline Non Verbal & 24 & $6,4 \%$ & 35 & $9,1 \%$ & 94 & $13,7 \%$ & 127 & $24,8 \%$ & 29 & $6,1 \%$ & 38 & $9,3 \%$ \\
\hline Total & 376 & & 385 & & 688 & & 513 & & 473 & & 408 & \\
\hline
\end{tabular}


Table 7b. Verbal and Non Verbal acts.

\begin{tabular}{|c|c|c|c|c|c|c|c|c|c|c|c|c|}
\hline & \multicolumn{4}{|c|}{ G4 } & \multicolumn{4}{c|}{ G5 } & \multicolumn{3}{|c|}{ G6 } \\
\hline Acts & G4-1 & $\%$ & G4-2 & $\%$ & G5-1 & $\%$ & G5-2 & $\%$ & G6-1 & $\%$ & G6-2 & $\%$ \\
\hline Verbal & 192 & $86,5 \%$ & 473 & $93,1 \%$ & 411 & $89,7 \%$ & 291 & $88,7 \%$ & 529 & $94,0 \%$ & 301 & $87,5 \%$ \\
\hline Non Verbal & 30 & $13,5 \%$ & 35 & $6,9 \%$ & 47 & $10,3 \%$ & 37 & $11,3 \%$ & 34 & $6,0 \%$ & 43 & $12,5 \%$ \\
\hline Total & 222 & & 508 & & 458 & & 328 & & 563 & & 344 & \\
\hline
\end{tabular}

Communicative discourse is mainly formed by verbal discourse. In tables $7 \mathrm{a}$ and $7 \mathrm{~b}$ it is clearly shown that most sessions have a high percentage of oral discourse. In all classes except G2-2, the percentage of Verbal acts is over $86 \%$ reaching $94 \%$ in G6-1.

After learning how Verbal and Non Verbal discourse compound communicative class discourse, it is useful to see how each type of participant (teacher and students' group) behave in class. Table 8 shows the percentage of communicative acts implemented by each group of participants within each class. $T$ stands for teacher and $\mathrm{G}$ for group. The number besides $\mathrm{T}$ and $\mathrm{G}$ identifies teacher and students group and a number indicates the class period.

Table 8. Speakers' communicative acts.

\begin{tabular}{|c|c|c|c|c|}
\hline Sessions & T1-1 & G1-1 & T1-4 & G1-4 \\
\hline G1 & $66 \%$ & $34 \%$ & $56 \%$ & $44 \%$ \\
\hline & T2-1 & G2-1 & T2-2 & G2-2 \\
\hline $\mathrm{G} 2$ & $57 \%$ & $43 \%$ & $53 \%$ & $47 \%$ \\
\hline & T3-1 & G3-1 & T3-4 & G3-4 \\
\hline G3 & $53 \%$ & $47 \%$ & $68 \%$ & $32 \%$ \\
\hline
\end{tabular}

\begin{tabular}{|l|l|l|l|l|}
\hline & T4-1 & G4-1 & T4-4 & G4-4 \\
\hline G4 & $60 \%$ & $40 \%$ & $61 \%$ & $39 \%$ \\
\hline
\end{tabular}

\begin{tabular}{|l|l|l|l|l|}
\hline & T5-1 & G5-2 & T5-1 & G5-2 \\
\hline G5 & $41 \%$ & $59 \%$ & $63 \%$ & $37 \%$ \\
\hline
\end{tabular}

\begin{tabular}{|l|l|l|l|l|}
\hline & T6-1 & G6-1 & T6-5 & G6-5 \\
\hline G6 & $63 \%$ & $37 \%$ & $67 \%$ & $33 \%$ \\
\hline
\end{tabular}

Data show that students' contribution to communicative discourse in L2 classes is between $33 \%$ and $47 \%$ except in one case, G5-2, where it is higher, reaching $59 \%$. In spite of being higher than the rest of the groups, we do not believe that it is an excellent result as we always should have in mind that we are considering communicative acts made by the whole group of students.

Moving a step forward, we have focused on the quantity of verbal and non verbal discourse made by speakers according to the number of acts made. So, in table 9 we have distinguished between VA and NVA made by teachers (Tn) and each group of students 
(Sn) in all classes observing that NVA take place in all classes but with a low percentage, between $6 \%$ and $24 \%$, which means that Verbal discourse is around $76 \%$ in the lowest levels and 94\% in the highest ones ( S6-1; S3-1, S1-1, S4-2).

Table 9. Communicative acts per type of participant.

\begin{tabular}{|c|c|c|c|c|c|c|c|c|c|c|c|c|}
\hline G1 & T1-1 & $\% \mathrm{~T} 1-1$ & S1-1 & $\% \mathrm{~S} 1-1$ & \begin{tabular}{|c|} 
Total \\
AC1-1 \\
\end{tabular} & $\begin{array}{c}\% \\
\text { AC1-1 }\end{array}$ & $\mathrm{T} 1-2$ & $\mid \% \mathrm{~T} 1-2$ & S1-2 & $\% \mathrm{~S} 1-2$ & $\begin{array}{l}\text { Total } \\
\text { C1-4 }\end{array}$ & $\begin{array}{c}\% \\
\text { AC1-4 } \\
\end{array}$ \\
\hline Verbal Acts & 243 & $97,2 \%$ & 109 & $86,5 \%$ & 352 & $93,6 \%$ & 209 & $96,3 \%$ & 141 & \begin{tabular}{|l|}
$83,9 \%$ \\
\end{tabular} & 350 & $90,9 \%$ \\
\hline $\begin{array}{l}\text { Non Verbal } \\
\text { Acts }\end{array}$ & 7 & $2,8 \%$ & 17 & $13,5 \%$ & 24 & $6,4 \%$ & 8 & $3,7 \%$ & 27 & $16,1 \%$ & 35 & $9,1 \%$ \\
\hline Total & 250 & & 126 & & 376 & & 217 & & 168 & & 385 & \\
\hline G2 & $\mathrm{T} 2-1$ & $\% \mathrm{~T} 2$ & S2-1 & $\% \mathrm{~S} 2-1$ & \begin{tabular}{|c|} 
Total \\
AC2-1 \\
\end{tabular} & $\begin{array}{c}\% \mathrm{AC} 2- \\
1\end{array}$ & $\mathrm{~T} 2-2$ & $\%$ T2-2 & $\mathrm{S} 2-2$ & $\% \mathrm{~S} 2-2$ & $\begin{array}{l}\text { Total } \\
\text { C2-2 }\end{array}$ & $\begin{array}{c}\% \\
\text { AC2-4 }\end{array}$ \\
\hline Verbal Acts & 344 & $88,0 \%$ & 250 & $84 \%$ & 594 & $86 \%$ & 235 & $87 \%$ & 151 & $64 \%$ & 386 & $76 \%$ \\
\hline $\begin{array}{c}\text { Non Verbal } \\
\text { Acts }\end{array}$ & 47 & $12,0 \%$ & 47 & $16 \%$ & 94 & $14 \%$ & 35 & $13 \%$ & 86 & $36 \%$ & 121 & $24 \%$ \\
\hline Total & 391 & & 297 & & 688 & & 270 & & 237 & & 507 & \\
\hline G3 & T3-1 & $\% \mathrm{~T} 3-1$ & S3-1 & $\% \mathrm{~S} 3-1$ & \begin{tabular}{|c|} 
Total \\
AC3-1 \\
\end{tabular} & $\begin{array}{c}\% \\
\text { AC3-1 } \\
\end{array}$ & T3-2 & $|\% \mathrm{~T} 3-2|$ & S3-2 & $\% \mathrm{~S} 3-2$ & $\begin{array}{l}\text { Total } \\
\text { C3-4 }\end{array}$ & $\begin{array}{c}\% \\
\text { AC3-4 } \\
\end{array}$ \\
\hline Verbal Acts & 234 & $92,9 \%$ & 210 & $95,0 \%$ & 444 & $93,9 \%$ & 277 & $100,0 \%$ & 93 & $71,0 \%$ & 370 & $90,7 \%$ \\
\hline $\begin{array}{l}\text { Non Verbal } \\
\text { Acts }\end{array}$ & 18 & $7,1 \%$ & 11 & $5,0 \%$ & 29 & $6,1 \%$ & 0 & $0,0 \%$ & 38 & $29 \%$ & 38 & $9,3 \%$ \\
\hline Total & 252 & & 221 & & 473 & & 277 & & 131 & & 408 & \\
\hline G4 & T4-1 & $\% \mathrm{~T} 4-1$ & S4-1 & $\%$ S4-1 & \begin{tabular}{|c|} 
Total \\
AC4-1
\end{tabular} & $\begin{array}{c}\% \\
\text { AC4-1 } \\
\end{array}$ & T4-2 & $|\% \mathrm{~T} 4-2|$ & S4-2 & $\% \mathrm{~S} 4-2$ & $\begin{array}{l}\text { Total } \\
\text { C4-4 }\end{array}$ & $\begin{array}{c}\% \\
\text { AC4-4 } \\
\end{array}$ \\
\hline Verbal Acts & 122 & $91,0 \%$ & 70 & $79,5 \%$ & 192 & $86,5 \%$ & 302 & $98,1 \%$ & 171 & $85,5 \%$ & 473 & $93,1 \%$ \\
\hline $\begin{array}{l}\text { Non Verbal } \\
\text { Acts }\end{array}$ & 12 & $9,0 \%$ & 18 & $20,5 \%$ & 30 & $13,5 \%$ & 6 & $1,9 \%$ & 29 & $14,5 \%$ & 35 & $6,9 \%$ \\
\hline Total & 134 & & 88 & & 222 & & 308 & & 200 & & 508 & \\
\hline G5 & T5-4 & $\% \mathrm{~T} 5-4$ & S5-4 & $\%$ S5-4 & \begin{tabular}{|c|} 
Total \\
AC5-4 \\
\end{tabular} & $\begin{array}{c}\% \\
\text { AC5-4 } \\
\end{array}$ & T5-2 & $\%$ T5-2 & S5-2 & $\%$ S5-2 & $\begin{array}{l}\text { Total } \\
\text { C5-5 } \\
\end{array}$ & $\begin{array}{c}\% \\
\text { AC5-5 } \\
\end{array}$ \\
\hline Verbal Acts & 179 & $94,7 \%$ & 232 & $86,2 \%$ & 411 & $89,7 \%$ & 195 & $93,8 \%$ & 96 & $80,0 \%$ & 291 & $88,7 \%$ \\
\hline $\begin{array}{l}\text { Non Verbal } \\
\text { Acts }\end{array}$ & 10 & $5,3 \%$ & 37 & $13,8 \%$ & 47 & $10,3 \%$ & 13 & $6,3 \%$ & 24 & $20,0 \%$ & 37 & $11,3 \%$ \\
\hline Total & 189 & & 269 & & 458 & & 208 & & 120 & & 328 & \\
\hline G6 & T6-1 & $\% \mathrm{~T} 6-1$ & S6-1 & $\%$ S6-1 & \begin{tabular}{|c|} 
Total \\
AC6-1 \\
\end{tabular} & $\begin{array}{l}\% \text { A } \\
\text { C6-1 }\end{array}$ & T6-2 & $\%$ T6-2 & S6-2 & $\%$ S6-2 & $\begin{array}{l}\text { Total } \\
\text { C6-5 } \\
\end{array}$ & $\begin{array}{c}\% \\
\text { AC6-5 } \\
\end{array}$ \\
\hline Verbal Acts & 347 & $97,2 \%$ & 182 & $88,3 \%$ & 529 & $94 \%$ & 229 & \begin{tabular}{|l|}
$99,1 \%$ \\
\end{tabular} & 72 & $63,7 \%$ & 301 & $87,5 \%$ \\
\hline $\begin{array}{c}\text { Non Verbal } \\
\text { Acts }\end{array}$ & 10 & $2,8 \%$ & 24 & $11,7 \%$ & 34 & $6 \%$ & 2 & $0,9 \%$ & 41 & $36,3 \%$ & 43 & $12,5 \%$ \\
\hline Total & 357 & & 206 & & 563 & & 231 & & 113 & & 344 & \\
\hline
\end{tabular}

All classes seem to share a high level of teacher contribution to discourse whilst students scarcely participate.

On the other hand, there is evidence of a big contrast between the verbal and non verbal discourse among participants. Thus, we observe that teachers participation is 
mainly Verbal, being minimum their Non Verbal contribution. It is completely different students' behaviour as VA and NVA are always present in all groups. In spite of having different percentages, a considerable part of students' communicative discourse takes place in a Non Verbal way.

Being particularly concerned with students use of English in the FL classroom, we pay special attention to Verbal participation and results are shown on table 10.

Table 10. Classes extension in terms of total Verbal acts.

\begin{tabular}{|l|c|c|c|c|c|c|c|c|c|c|c|c|}
\hline Group & \multicolumn{2}{|c|}{ G1 } & \multicolumn{2}{c|}{ G2 } & \multicolumn{2}{c|}{ G3 } & \multicolumn{2}{c|}{ G4 } & \multicolumn{2}{c|}{ G5 } & \multicolumn{2}{c|}{ G6 } \\
\hline Session & G1-1 & G1-2 & G2-1 & G2-2 & G3-1 & G3-2 & G4-1 & G4-2 & G5-1 & G5-2 & G6-1 & G6-2 \\
\hline Verbal acts & 352 & 350 & 594 & 386 & 444 & 370 & 152 & 473 & 411 & 291 & 529 & 301 \\
\hline
\end{tabular}

Comparison between tables 9 and 10 clearly shows how Verbal Discourse is always shorter than Communicative Discourse but we are interested in knowing more about participants' Verbal contribution. Figure 1 shows speakers' Verbal contribution to discourse during the two studied classes of each instructed setting.

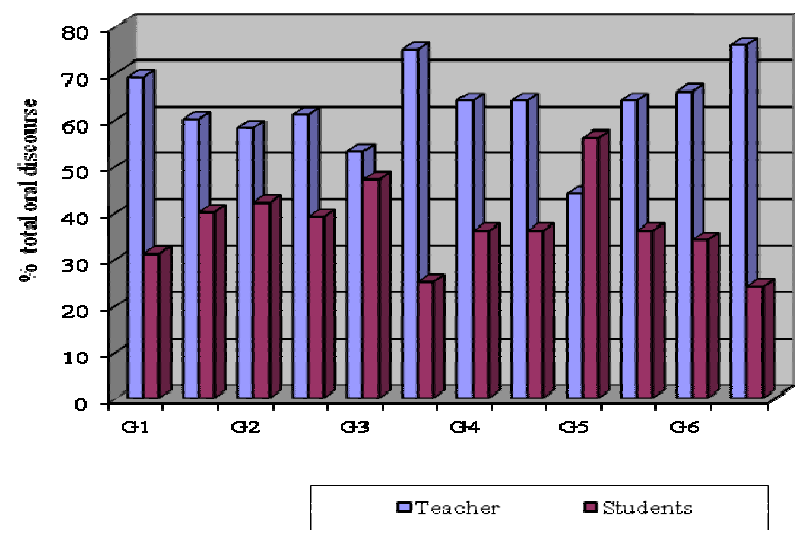

Figure 1. Participant's contribution to Verbal Discourse.

Some observations can be made from these results. First of all, excepting G4 where the level is exactly the same, all sessions show different Students' Verbal participation percentages in each class, even within the same group, although there seems to be a tendency to maintain a margin of $10 \%$. Only in one case (G5) the difference between sessions is as high as 20 points. A question arises in our minds 'why do learners speak more in one class than in another if they are being taught by the same teacher and share the context with the same partners?'

It also strikes us the unbalanced speakers' participation level. Only two out of twelve classes show certain equilibrium between the two groups of speakers: one group of participants formed by as many elements as students are in the classroom and the other one with only one element, the teacher. 
As the graphic above reflects, it is the teacher who always seems to consume the greatest part of the verbal discourse generated. The average is $60 \%$ and sometimes reaches even $75 \%$ which means that L2 learners' Verbal participation marks are very low. We have observed that there is only one session where the group of learners participate a little more than the teacher. It has taken place in session G5-2 where learners produced the $56 \%$ of the total Verbal participation in class. In the rest of the L2 classes the level of students' participation was lower, between $30 \%$ and $40 \%$ and it even decreased to $24 \%$ (G3-2).

We have also checked that some students have very few opportunities to speak in English during the L2 class because of the group size. That is the case in G3-1, where students have produced $47 \%$ of the total Verbal Discourse. It is not a low percentage, almost $50 \%$ which seems to be quite balanced but considering that there are twenty-two pupils in class it is not difficult to understand that students have had very little opportunities to speak. In contrast, we find G5-2 where students' oral production has been $56 \%$. For a group with only 9 students getting higher percentage of Verbal Discourse than the teacher means that each learner has had a lot of opportunities to speak.

To sum up, we could say that speakers do not produce the same quantity of speech in different classes and also that students do not contribute to Verbal discourse with the same amount of Verbal acts than their teachers.

In the next section, we will explore the language chosen by students for their Verbal contributions to discourse.

\subsection{Results related to learners' $L 2$ output in $L 2$ class}

In the observation period as well as in the corpus analysis we have witnessed that teachers and students use quite often mother tongue (L1) and target language (L2) during L2 classes.

Table 11a. Language used by students in G1, G2 and G3.

\begin{tabular}{|c|c|c|c|c|c|c|c|c|c|c|c|}
\hline \multicolumn{4}{|c|}{ G1 } & \multicolumn{4}{c|}{ G2 } & \multicolumn{3}{c|}{ G3 } \\
\hline \multicolumn{2}{|c|}{ G1-1 } & \multicolumn{2}{|c|}{ G1-2 } & \multicolumn{2}{c|}{ G2-1 } & \multicolumn{2}{c|}{ G2-2 } & \multicolumn{2}{c|}{ G3-1 } & \multicolumn{2}{c|}{ G3-2 } \\
\hline L2 & L1 & L2 & L1 & L2 & L1 & L2 & L1 & L2 & L1 & L2 & L1 \\
\hline $64 \%$ & $36 \%$ & $68 \%$ & $32 \%$ & $46 \%$ & $54 \%$ & $46 \%$ & $54 \%$ & $95 \%$ & $5 \%$ & $84 \%$ & $16 \%$ \\
\hline
\end{tabular}

Table 11b. Language used by students in G4, G5 and G6.

\begin{tabular}{|c|c|c|c|c|c|c|c|c|c|c|c|}
\hline \multicolumn{3}{|c|}{ G4 } & \multicolumn{3}{c|}{ G5 } & \multicolumn{4}{c|}{ G6 } \\
\hline \multicolumn{2}{|c|}{ G4-1 } & \multicolumn{2}{|c|}{ G4-2 } & \multicolumn{2}{c|}{ G5-1 } & \multicolumn{2}{c|}{ G5-2 } & \multicolumn{2}{c|}{ G6-1 } & \multicolumn{2}{c|}{ G6-2 } \\
\hline L2 & L1 & L2 & L1 & L2 & L1 & L2 & L1 & L2 & L1 & L2 & L1 \\
\hline $46 \%$ & $54 \%$ & $54 \%$ & $46 \%$ & $68 \%$ & $32 \%$ & $44 \%$ & $56 \%$ & $32 \%$ & $68 \%$ & $32 \%$ & $68 \%$ \\
\hline
\end{tabular}


Results show that there are great differences among each class period.

(i) In some classes, students seem to speak in L2 most of the time (G3-1 and 2).

(ii) In other classes, although students speak more in English than in Spanish, being the percentage of L2 used not very high (around 70\%) as in G1-1 and 2 or in G51 .

(iii) There are also classes where it is possible to observe a very similar level of use of L1 and L2 (G2-1, G2-2, G4-1; G4-2; G5-2).

(iv) Finally, we have also observed that, in some classes learners tend to speak more in Spanish than in English. (G6-1 and 2).

Surprisingly, the older students (G6), with four years experience as L2 learners, have mainly used the mother tongue.

When comparing the amount of Verbal discourse made by students with the total Verbal discourse made in class (see table 12) it is possible to understand that students' L2 output is very little in general in spite of differences among classes of different groups $(\mathrm{G} 6-2=6 \%$ versus $\mathrm{G} 3-1=45 \%)$ and also between classes with the same members $(\mathrm{G} 5-1=$ $38 \%$ versus $\mathrm{G} 5-2=14 \%$ )

Table 12. Students L2 verbal discourse over total Verbal Discourse.

\begin{tabular}{|c|c|c|c|c|c|c|c|c|c|c|c|c|}
\hline & G1-1 & G1-2 & G2-1 & G2-2 & G3-1 & G3-2 & G4-1 & G4-2 & G5-1 & G5-2 & G6-1 & G6-2 \\
\hline Sts L2 verbal acts & 70 & 96 & 114 & 70 & 200 & 80 & 27 & 93 & 157 & 42 & 58 & 17 \\
\hline $\begin{array}{c}\text { Total classroom } \\
\text { verbal discourse }\end{array}$ & 352 & 350 & 594 & 386 & 444 & 370 & 192 & 473 & 411 & 291 & 529 & 301 \\
\hline $\begin{array}{c}\% \text { students L2 } \\
\text { discourse }\end{array}$ & $20 \%$ & $27 \%$ & $19 \%$ & $18 \%$ & $45 \%$ & $22 \%$ & $14 \%$ & $20 \%$ & $38 \%$ & $14 \%$ & $11 \%$ & $6 \%$ \\
\hline
\end{tabular}

Students in G6 are the ones who have scarcely used L2 in their output, scarcely 6\% of the total VD, that is Teacher plus students' verbal discourse either in the mother tongue or in the target tongue. Seven out of the twelve classes show a percentage between $10 \%$ and $20 \% ; 2$ classes are between $21 \%$ and $30 \% ; 1$ class is near $40 \%$ and 1 class gets $45 \%$. All this reflects FL classes where the use of L1 over-exceeds the use of the target language.

These low figures can be even lower if we compare students' L2 contribution with the total communicative discourse generated in class.

In the following table it is shown the quantity of verbal acts made by learners in L2 during each class period. Comparing them with the total number of communicative acts we obtain the following percentages. 
Table 13. Learners' L2 output in relation to total Communicative Discourse.

\begin{tabular}{|c|c|c|c|c|c|c|c|c|c|c|c|c|c|}
\hline & \multicolumn{2}{|c|}{$\mathrm{G} 1$} & \multicolumn{2}{c|}{$\mathrm{G} 2$} & \multicolumn{2}{c|}{$\mathrm{G} 3$} & \multicolumn{2}{c|}{$\mathrm{G} 4$} & \multicolumn{2}{c|}{ G5 } & \multicolumn{2}{c|}{$\mathrm{G6}$} \\
\hline & 1 & 2 & 1 & 2 & 1 & 2 & 1 & 2 & 1 & 2 & 1 & 2 \\
\hline Learners' Verbal acts in L2 & 70 & 96 & 114 & 70 & 200 & 80 & 27 & 93 & 157 & 42 & 58 & 17 \\
\hline $\begin{array}{c}\text { Total communicative acts } \\
\text { in classroom discourse. }\end{array}$ & 376 & 385 & 688 & 513 & 473 & 408 & 222 & 508 & 458 & 328 & 563 & 344 \\
\hline Learners' L2 output & $19 \%$ & $25 \%$ & $17 \%$ & $14 \%$ & $42 \%$ & $20 \%$ & $12 \%$ & $18 \%$ & $34 \%$ & $13 \%$ & $10 \%$ & $5 \%$ \\
\hline
\end{tabular}

The lowest part of the table shows the percentage of communicative discourse that occupies learners' oral production in English. The maximum percentage, obtained by G31 represents only $42 \%$ of the total communicative discourse. The rest of the groups are below the third part of it and it is specially striking G6-1 and G6-2 low percentages.

According to the times students use L2 in their speech, any observer could have the impression that learners do not use English very much in class and that it is not really the language most frequently used. On the contrary, there seems to be a constant code switching between L1 and L2.

It would be extremely interesting to know the exact quantity of L2 used by each student, but due to the impossibility to recognize all students' voices during the transcription process we have calculated an average quantity for each student considering each class ratio.

Table 14. Quantity of L2 Verbal Acts per student.

\begin{tabular}{|c|c|c|c|c|c|c|c|c|c|c|c|c|}
\hline & \multicolumn{2}{|c|}{ G1 } & \multicolumn{2}{c|}{ G2 } & \multicolumn{2}{c|}{ G3 } & \multicolumn{2}{c|}{ G4 } & \multicolumn{2}{c|}{ G5 } & \multicolumn{2}{c|}{ G6 } \\
\hline & 1 & 2 & 1 & 2 & 1 & 2 & 1 & 2 & 1 & 2 & 1 & 2 \\
\hline L2 verbal acts & 70 & 96 & 114 & 70 & 200 & 80 & 27 & 93 & 157 & 42 & 58 & 17 \\
\hline Ratio & 15 & 15 & 10 & 10 & 22 & 22 & 21 & 21 & 9 & 9 & 28 & 28 \\
\hline L2 acts/student & 4,7 & 6,4 & 11,4 & 7 & 9,1 & 3,6 & 1,3 & 4,4 & 17,4 & 4,7 & 2,1 & 0,6 \\
\hline
\end{tabular}

The difference between the class with the highest student L2 output (G5-1=17'4) and the lowest one $\left(\mathrm{G} 6-2=0^{\prime} 6\right)$ is remarkably large. Both groups with low ratio (G2 and G5) obtain better results although they only get good results in one of the two analysed sessions. In contrast, G3-1 shows better results than other smaller groups such as G1 or G2 in session 2.

Finally, the media of L2 verbal acts per student is 6'1. Only five out of the twelve classes are on or above the media and the remaining seven are quite under it. There is only one group of students (G2) in which students' level of L2 use is above the media in both sessions. This beginner group, in spite of their short age seems to use the new language more than others with higher knowledge of L2. 


\section{Discussion}

This research is an attempt to gain a better knowledge of current FL classrooms. Similarly to Sinclair and Coulthard (1975); Tsui (1994, 2008) or Walsh, (2006) we believe the best way, if not the only one, to understand classes is observing and analysing discourse. Our study shows that language, paralanguage and kinesics are constantly mixing when people communicate, as Poyatos (1994) points out but we prefer the term Communicative Discourse because Verbal and Non Verbal elements are mixed in the interaction with the function of communicating.

To investigate the communicative discourse generated in the twelve analysed L2 classes, we have applied CODAM, a model of analysis whose smallest unit is the communicative act as there are less or equal number of communicative moves than communicative acts and equal or more communicative moves than communicative turns.

In this paper, we have focused on speakers' oral participation during L2 classes, but we have no doubt that CODAM is a very helpful tool to gain a deeper insight into any teaching-learning process. Classroom transcriptions can be exploited by in-service teachers for self reflection after teaching, as Harfitt (2008) suggests. They can also be extremely useful for future teachers to learn more about classes and about effective and noneffective teaching, and also for researchers eager to make either macro studies of the whole class or unit implementation or micro studies focussing on specific fragments of the teaching-learning process.

\section{Conclusions}

Relevant conclusions can be drawn from our data. First of all, results show that a different quantity of communicative discourse is generated among speakers in the same period of time. Classroom communicative discourse length varies from one L2 class to another as there are a different number of communicative acts in each analysed class. That means that in the same period of time, some speakers manage to produce more communicative acts than others.

Secondly, we have checked that Verbal and Non Verbal acts coexist in all classes although most of NV acts are made by learners. Being the main objective of our investigation to establish how much participants speak in the English class we have focused on oral participation, and our third conclusion is that most of the verbal discourse generated corresponds to the teacher. We have only found one case in which the teacher's verbal discourse is under $50 \%$ of the total verbal discourse but in some classes teacher's talk occupies even $75 \%$. This unequal proportion of participation between individuals in class should be an issue for teachers' self-reflection. Only $25 \%$ classroom discourse is formed by the whole group of students, which gives an indication of the little opportunities that 25 pupils have had to develop their speaking skill during the class.

A fourth conclusion is related to ratio. Against we had expected, we cannot affirm that group size affects students' participation level because surprisingly, we have observed groups with smaller ratio not always obtain higher level of oral output. We think that lowl ratio does not imply high students' oral participation. 
In general, learners show little participation in class and their use of Englis in the L2 class is quite low. Although it depends on the groups and also on the class periods which leads us to think that there are other factors appart from the individuals that invite students to speak more or less in English.

Further research should be done to investigate these differences among classes. As teachers play a relevant role when deciding the English-learning atmosphere to be created in class (Wong, 2010), in future studies we would like to investigate teachers' attitudes not only related to language but also with important decissions made while teaching.

\section{REFERENCES}

Allwright, D. y Bailey, K. (1991). Focus on the Language Classroom. Cambridge. Cambridge University Press.

Arnaiz, P. y Peñate, M. (2004). "El papel de la producción oral (output) en el proceso de aprendizaje de una lengua extranjera (LE): el estudio de sus funciones". Porta Linguarum, 1: $37-60$.

Bailey, K. M. (1991). "Diary studies of classroom language learning: the doubting game and the believing game", in E. Sadtono (ed.) Language acquisition and the second/foreign language classroom. (Anthology Series 28) Singapore. SEAMEO, Regional Language Center. (60102)

Bellack, A.A., Kliebard, H.M., Imán; R.T. y Smith, F.L. (1966). The Language of the Classroom. New York. Teachers College Press, Columbia University.

Blackemore, D.(1992) Understanding utterances. Oxford. Blackwell.

Chaudron, C. (1988). Second Language Classrooms. Cambridge. Cambridge University Press.

Cortés Rodríguez, L. y Camacho Adarve, $\mathrm{M}^{\mathrm{a}}$ M. (2003) ¿Qué es el análisis del discurso? Barcelona. Octaedro. E.U.B.

Firth, H J.R. (1957). Papers in linguistics 1934-1951. London. Oxford University Press.

Halliday, M.A.K. (1973). Explorations in the functions of language. London, Edward Arnold.

Halliday, M.A.K y Hasan, R. (1994 [1985]). An Introduction to Functional Grammar. London: Edward Arnold.

Harfitt, G. (2008). "Exploiting Transcriptions of Identical Subject Content Lessons". English Language Teaching journal, 62 (2). 173-181.

Hopkins, D. (1985). A Teacher's guide to Classroom Research. Philadelphia. Open University Press.

Marton, F y Tsui, A.M.B. (2004). Classroom Discourse And The Space Of Learning. Nahwah, N.J. Lawrence Erlbaum Associates.

McCarthy, M. (1991). Discourse Analysis for Language Teachers. Cambridge. Cambridge University Press

McCarthy, M y Carter, R (1994). Language as Discourse: perspectives for language Teaching. London. Longman.

Poyatos, F. (1994). Paralenguaje, kinésica e interacción. Madrid. Istmo.

Salaberri, S. (1999). El Discurso del Profesor en el Aula y su relación con las tareas de aprendizaje. Servicio de publicaciones Universidad de Almería.

Seedhouse, P. (2004). The Interactional Architecture of the Second Language Classroom: A Conversational Analysis Perspective. Oxford. Blackwell. 
Sinclair, J. Mch y Coulthard, M (1975). Towards an analysis of discourse. Oxford. Oxford University Press.

Tsui, A. B. M. (1994). English Conversation. Oxford. Oxford University Press.

Tsui, A. B. M. (1995). Introducing classroom Interaction. London. Penguin.

Tsui, A. B. M. (2008). "Classroom Discourse. Approaches and Perspectives", in J. Cenoz y N.H. Homberger (eds.) The Encyclopedia of Language and Education (Vol. 6: Knowledge About Language. 261-272. New York. Springer.

Walsh, S. (2006). Investigating Classroom Discourse. New York. Routledge.

Wong, R. M. H. (2010). "The Effectiveness of using English as the sole medium of Instruction in English Classes: Student Responses and improved English Proficiency”. Porta Linguarum, 13: $119-130$. 